\title{
PUBLIC FUNDING OF ICT IN BULGARIAN SCHOOL EDUCATION (2012-2015)
}

\section{Teodora Varbanova ${ }^{1}$}

\begin{abstract}
This article aims to present state policy in respect of the provision of ICT in schools and more specifically computerized workplaces. The definition of the author for computerized workplaces: desktop, laptop, terminal or (hybrid) tablet. For this purpose, the presented and analyzed data are from the implementation of the Ministry of Education and Science in Bulgaria National Program "Information and communication technologies (ICT) in the schools" for the period: school years 2012/2013, 2013/2014 and 2014/2015. The data are obtained from the Ministry of education and science in February 2015 in response to a request for access to public information by the author. In this article some of the analyzed data give objective information about the state funding for securing computerized workplaces and the total amount of investments, and effectively covered schools, for the survey period.
\end{abstract}

JEL Classification Numbers: I21; I25; I28; DOI: http://dx.doi.org/10.12955/cbup.v5.1040

UDC Classification: $35 ; 37$

Keywords: ICT, education, public funds, schools, computers, students

\section{Introduction}

The introduction of new technologies, such as broadband internet and personal devices with access to the global network has had a most noteworthy effect on education. A large number of students are connected to the global network either via computers at home or via personal devices - primarily cell phones with access to the Internet. At present, schools are lagging behind with personalizing education and, more importantly, with providing a computerized workstation for each student. Recent studies pertaining to the use of ICT in schools are:

- The PISA survey in 2012 - Program for International Student Assessment of the Organization for Economic Co-operation and Development (OECD) intended as a periodical standardized assessment of 15-year-old students. This was the first time a computer - based problemsolving module was introduced. According to the survey, an average of $94 \%$ of students in OECD countries have computers at home which they also use for educational purposes. An average of $72 \%$ use computers at school, yet in some countries less than $50 \%$ of students have claimed so. An average of $94 \%$ of the surveyed students have at least one computer at home; 93\% of Bulgarian students also have at least one computer at home (Petrova, 2013).

- The European Commission's Survey of Schools: ICT in Education, conducted in the 2011/2012 academic year, which included 31 countries - the 27 EU members, Iceland, Norway, Croatia and Turkey, and a total of 190000 respondents (teachers, students, principals). The survey defined 'computer' as 'a PC or laptop, netbook or tablet, which is used for educational purposes at school, regardless of whether it is connected to the Internet or not. The survey was aimed at assessing the different aspects of ICT in schools among students in the fourth, eighth and eleventh (general and vocational education) grades.

The purpose of this article is to present the country's policy regarding the provision of ICT in schools and computerized workstation in particular. The definition of the author for computerized workplaces is: desktop, laptop, terminal or (hybrid) tablet. The data from the National Program "Information and Communication Technologies (ICT) in Schools" for the academic years 2012/2013, 2013/2014 and 2014/2015 of the Bulgarian Ministry of Education and Science will be used for the purposes of this article. The data are obtained from the Ministry of education and science in February 2015 in response to a request for access to public information by the author. This article analyzes part of the data which presents objective information about the financial provision for computerized workstations, as well as the total amount of the investments made, as well as the schools which were and were not covered in the assessed period.

\section{Bulgaria's place in comparison with other European Union countries}

As of now, no information has been released on the actual number of computerized workstations in Bulgarian schools and it is difficult to acquire such data since the presence of a computer does not guarantee that it is being used as a computerized workstation. Before the National Program

\footnotetext{
${ }^{1}$ Faculty of Economics and Business Administration, Sofia University, tedche@ hotmail.com
} 
"Information and Communication Technologies (ICT) in Schools" of the Ministry of Education and Science, the only national provision of computers was in 2005-2007 when "more than 65,000 computers" were divided between all Bulgarian schools as a measure for the fulfillment of the National strategy for introducing ICT in Bulgarian schools. Since then, there have not been any centralized deliveries, and it has been up to the schools to decide how much of their delegated budgets should be spent on ICT. Numerous businesses and non-governmental organizations supposedly took up the initiative to give ICT equipment to schools for the period 2008-2012 but there is no consolidated information. The only official information released about the provision of computers in schools is the one from the aforementioned survey of the European Commission Survey of Schools: ICT in Education (European Schoolnet, University of Liège, 2012). Table 1, in which the results for Bulgaria are compared to averaged results for the EU countries, shows the ratio of computerized workstations to 100 students. The EU results show a decrease in the ratio in the higher grades. Even though Bulgaria is significantly lagging behind compared to the other EU countries, the data show a compliance with European tendencies: elementary school pupils have the least access to ICT in schools and students in vocational education have the largest number of computerized workstations at their disposal. Bulgaria rates among the last five countries in the survey, together with Italy, Romania, Greece and Turkey. There are primarily PCs, and the ratio of a student to a workstation connected to the Internet is 1 to 13, the EU standard being 1 to 7. Laptops are a scarcity, with a ratio of 1 to 125 . More than $80 \%$ of computers are placed in computer labs. As for broadband internet access, Bulgaria is among the leading countries, with a mere $4-5 \%$ of students attending schools not connected to the Internet.

\begin{tabular}{|l|r|r|lr|r|}
\hline \multicolumn{6}{|l|}{ Table 1: The ratio of computerized workstations to 100 pupils } \\
\hline Country & $\mathbf{4}^{\text {th }}$ grade & $\mathbf{8}^{\text {th }}$ grade & $\begin{array}{l}\mathbf{1 1}^{\text {th }} \text { grade - General } \\
\text { education }\end{array}$ & $\begin{array}{l}\mathbf{1 1}^{\text {th }} \text { grade - Vocational } \\
\text { education }\end{array}$ \\
\hline BULGARIA & 6.5 & 9.4 & 8.7 & 15.6 \\
\hline EU Average & 14.5 & 21.1 & 23.2 & 33.6 \\
\hline Source: Authors
\end{tabular}

8th -11th grade students fall in the scope of the survey which assesses the usage of technology in class (shown in Table 2). Between $65 \%$ and $71 \%$ of students utilize school computers while between $19 \%$ and $22 \%$ use personal laptops. The results concerning cell phone usage are most curious, with $40 \%$ to $46 \%$ having claimed that they use one. Compared to other EU countries, the percentage is significantly higher. Despite the negative tendencies concerning the student-computer ratio, Bulgaria rates high among the countries using ICT at school for educational purposes, particularly via cell phones.

\begin{tabular}{|l|l|r|r|r|}
\hline \multicolumn{2}{|l|}{ Table 2: Using technology in class } \\
\hline \multirow{2}{*}{ Level of education } & Country & $\begin{array}{l}\text { Personal cell } \\
\text { phone }\end{array}$ & Personal laptop & School computer \\
\hline \multirow{2}{*}{$\mathbf{8}^{\text {th }}$ grade } & BULGARIA & $39.5 \%$ & $19.3 \%$ & $70.6 \%$ \\
\cline { 2 - 5 } & EU average & $28 \%$ & $11.2 \%$ & $53.3 \%$ \\
\hline $\begin{array}{l}\mathbf{1 1}^{\text {th }} \text { grade - General } \\
\text { education }\end{array}$ & BULGARIA & $46.1 \%$ & $21.6 \%$ & $67.5 \%$ \\
\cline { 2 - 5 } & EU average & $34.6 \%$ & $10.7 \%$ & $50.5 \%$ \\
\hline $\begin{array}{l}\mathbf{1 1}^{\text {th }} \text { grade - } \\
\text { Vocational education }\end{array}$ & BULGARIA & $44.8 \%$ & $21.9 \%$ & $65.2 \%$ \\
\cline { 2 - 5 } & EU average & $45.6 \%$ & $15.5 \%$ & $64.3 \%$ \\
\hline Source: Authors
\end{tabular}

Based on a number of criteria the European Commission Survey of Schools: ICT in education divides schools in three levels of digital provision, defined as follows: the school has broadband connection to the Internet (more than $10 \mathrm{mbps}$ ), as well as one of the following: a website, an e-mail for students and teachers, a local web, a virtual educational environment.

- Schools with a high level of digital provision

- Schools with partial digital provision

- Schools with a low level of digital provision that have little or no Internet access

$19 \%$ of 4th grade Bulgarian schools and $14 \%$ of 8 th grade Bulgarian schools fall in the last category. Only 11th grade schools are anywhere near close to the average EU levels. 


\section{National ICT in Schools Program}

The data cited above concerns the academic 2011/2012 year. In 2012, a National Program "Information and Communication Technologies (ICT) in schools" of the Bulgarian Ministry of Education and Science was introduced and approved. Its primary aim was to financially aid schools in renewing ICT equipment by "guaranteeing a minimum of technological provision by facilitating each school with computer terminal solutions" (National Program "Information and Communication technologies (ICT) in the schools" for the school year 2012-2013, 2013). In the four years that the program covers, the schools are to utilize the financial aid given and to renovate ICT equipment. As of 2012 , the program fixates an opportunity for providing computerized workstations, namely terminal work stations. The program lists the following benefits:

- Obtaining and renovating terminal based workstations is cheaper: one server caters for numerous workstations; the only expenses have to do with renovating only the server since the other components last longer

- The cost of maintenance is lower: this is an important argument when it is taken into consideration the fact that most schools in the country cannot afford the services of professionals and the role of ICT support and maintenance is often taken up by Informatics and/or IT teachers.

- The technology is easily applicable to the learning process.

The criteria the program requires are clear: at least 3 servers per school, or at least one server per 13 pupils, both of which provide a maximum of 39 workstations per school. The budget is 6500000 $\mathrm{BGN}$, of which up to $5000000 \mathrm{BGN}$ is designated for renovating the present technologies. Each school in the country applies for centralized financing by stating in advance the number of workstations needed and the amount for co-funding. The maximum price per workstation allowed by the Ministry of Education and Science is 750 BGN. Should a school manage to provide a workstation at a lower price, the rest of the money can be used for purchasing more workstations or for other ICT related expenses. The process is completed on a school level but the Ministry of Education and Science provides two specifications for minimal technical requirements for terminal solutions of a high-end and a low-end performance.

During the first year of the program a total of 1168 schools applied. In order to fit the financial restrictions, only 496 schools were approved (see Table 3 ).

During the second year - school year 2013/2014 - the requirements were slightly altered. Schools which had a pre-existing network received 700 BGN per workstation while schools which required building a network received $750 \mathrm{BGN}$, and it was expected of the Internet providers to include setting up the network in the final price. Whether a school was approved or not depended on what percentage of the sum they co-funded 836 schools applied and 516 were approved (see Table 3).

During the third year - the school year 2014/2015 - the program was significantly changed regarding ICT equipment. In addition to the initial "terminal solutions," "personal and portable computers," tablets and various hardware, such as multimedia projectors, interactive whiteboards and software products were included (National Program "Information and Communication technologies (ICT) in the schools" for the school year 2014-2015, 2015). The maximum price allowed was increased for the following:

- Terminal - 850 BGN (app. 430 EUR)

- Computer - 800 BGN (app. 400 EUR)

- Laptop - 800 BGN (app. 400 EUR)

- Tablet - 500 BGN (app. 250 EUR)

- Projector - 1000 BGN (app. 500 EUR)

- Interactive whiteboard - 1000 BGN (app. 500 EUR)

Each school could apply for additional hardware and software products, again providing exact cofunding. Schools were required to fill out a survey in which they had to sort out their priorities - the priority of each product they were applying for if it were to be bought. Two additional components were added when considering a school: 
- Innovative capacity of the school, which was defined by the school's readiness to measure its e-maturity by filling out an international survey conducted by a European Union project

- A school action plan - filled in a form provided by the Ministry of Education and Science

The final rating was by component and not by school as it has been in the previous two years, i.e. a school could receive funding for some of the components it had applied for but not necessarily for all of them. For the first time there was separate funding for all applied Protected Schools and all the components they applied for were funded. Totally 1171 schools applied in the school year 2014/2015 but only 623 were approved (see Table 3 ).

The data for the schools which applied and those which were funded by the National program "ICT in schools" give precise information about the interest toward the program - a program which allows schools to facilitate computerized workstations according to the latest educational standards. For the first three years of the programs, which are analyzed in this article, the number of schools is 2479 elementary schools, secondary schools, high schools, vocational schools, evening high schools and prison schools. Table 3 shows the percentage of schools which took part in the program and were funded compared to the total number of schools in the country for each year of the program.

\begin{tabular}{|l|r|r|r|}
\hline \multicolumn{1}{|l|}{ Table 3: Covered and not covered schools - by years } \\
\hline & $\begin{array}{c}\text { School Year } \\
\mathbf{2 0 1 2 / 2 0 1 3}\end{array}$ & $\begin{array}{c}\text { School Year } \\
\mathbf{2 0 1 3 / 2 0 1 4}\end{array}$ & $\begin{array}{c}\text { School Year } \\
\mathbf{2 0 1 4 / 2 0 1 5}\end{array}$ \\
\hline Totally Applied Schools & 1168 & 836 & 1171 \\
\hline Approved for funding & 496 & 516 & 623 \\
\hline $\begin{array}{l}\text { Percentage of schools approved for } \\
\text { funding from all applied schools }\end{array}$ & $42.47 \%$ & $61.72 \%$ & $53.20 \%$ \\
\hline $\begin{array}{l}\text { Percentage of applied schools compared } \\
\text { to all the schools in the country }\end{array}$ & $47.12 \%$ & $33.72 \%$ & $47.24 \%$ \\
\hline $\begin{array}{l}\text { Percentage of funded schools compared } \\
\text { to all the schools in the country }\end{array}$ & $20.01 \%$ & $20.81 \%$ & $25.13 \%$ \\
\hline Source: Authors & & & \\
\hline
\end{tabular}

Taking into account the information in Table 3, the following conclusions can be made:

- Fewer than $50 \%$ of all the schools in the country applied for the program. The main conclusion that can be made is that the schools that did not apply is due to lack of delegated budget funding and cannot afford to spend money on renovating or purchasing computerized workstations. IT in secondary schools and Informatics and IT in high schools are compulsory subjects in Bulgarian schools. Since the last national program that facilitated schools with computers was in 2005-2007, it is logical to deduce that obsolete technology is being used in computer labs throughout the country. Even if some of the schools renovated their ICT equipment through special programs or with their own budget, they do not represent $50 \%$ of Bulgarian schools. The second, and more unpleasant by far, conclusion is that more than $50 \%$ of the schools in Bulgaria are not interested in updating their computer labs.

- Interest in the program significantly dropped in the second year. A logical explanation is that what schools want for technology is different from the pre-defined "terminal solutions". This is probably why the program was opened for different types of technology in its third year when the number of applicants was the same as the first year.

- Even though the program's budget of 5000000 BGN remained unchanged for the first three years, the number of approved schools increased. Due to increase of co-funding in 3rd year.

- A detailed analysis shows the following:

- In the school year 2012/2013 the following areas have the highest percentage of approved schools: Shumen (39\%), Varna (36\%) and Vidin (31\%). Ruse (10\%), Pazardzhik (8\%) and Kardzhali (4\%) have the lowest.

- In the school year 2013/2014 40\% of all the schools in the Yambol area were funded, as well as 39\% of schools in the Varna area and 30\% in the Burgas area.

- In the school year 2014/2015 42\% of Yambol schools, as well as 36\% of Sliven, Vratsa and Pleven schools, were funded. Lovech (11\%), Veliko Tarnovo (15\%) and Vidin (15\%) are among the areas which received the least funding. 
- For the entire duration of the program, $77 \%$ of all the schools in the Vratsa area were funded, as were $66 \%$ of the schools in the Pleven and Shumen areas. Pazardzhik (26\%), Kardzhali (35\%) and Stara Zagora (35\%) are at the bottom of the rating.

- More than $50 \%$ of all the schools in 15 areas in the country were funded.

- It is important to note that the total number of funded schools does not mean: funded unique schools. 35 schools received funding for all three years of the program. A lot of schools were part of the program for two of the three years. 1227 out of 2479 schools were funded.

\begin{tabular}{|l|l|l|}
\hline $\begin{array}{l}\text { Figure 1: Schools which took part in the program and schools which did not for the first three years of the } \\
\text { program }\end{array}$ & $\begin{array}{c}\text { Covered } \\
\text { schools } \\
49 \%\end{array}$ \\
\hline $\begin{array}{c}\text { Uncovered } \\
\text { Schools } \\
51 \%\end{array}$ & $\begin{array}{c}49 \\
0\end{array}$ \\
\hline Source: Authors & & \\
\hline
\end{tabular}

\section{Public funding of ICT in school education}

The National program "ICT in Schools" supports schools in purchasing computerized workstations by co-funding. The final sum of a computerized workstation is defined by the Bulgarian Ministry of Education and Science, and each school applies for a number of computerized workstations, stating the percentage of the co-funded sum it can cover. The program provides the rest of the money for any number of schools until reaching the financial limit. For the first three years of the program the Ministry of Education and Science has provided a total of 22522849 BGN.

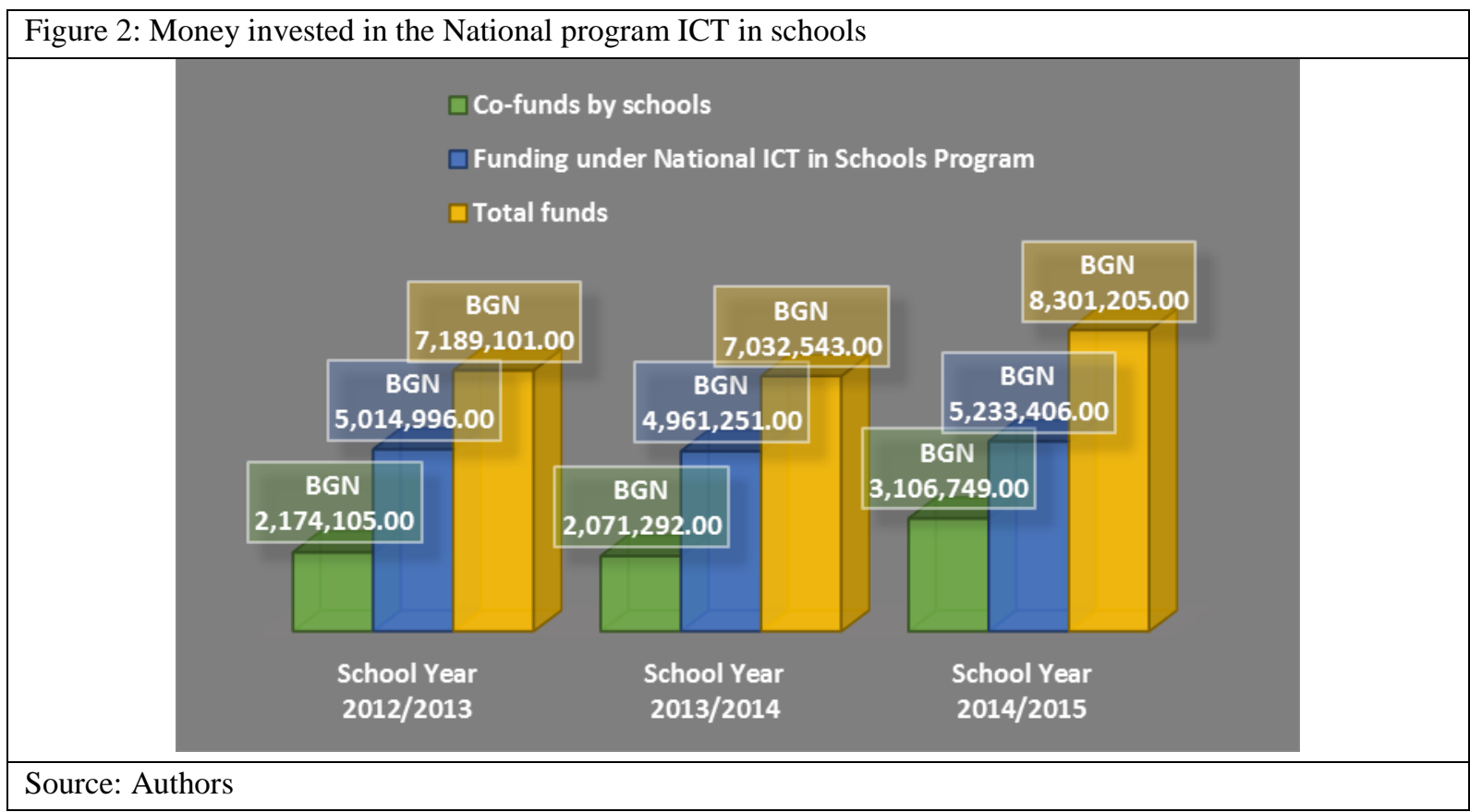


- As can be seen, there is a sudden decrease in the second year of the program but in the third year there is a pronounced increase. This results from the increase in the budget (courtesy of the Ministry of Education and Science and achieved by using additional unused funds from other programs) and proves that there is more interest in the program when schools have a variety of technologies to choose from.

- A detailed analysis shows the following:

- In the school year $2012 / 2013$ schools in the Sofia area $(38.41 \%)$, in the Targovishte area $(38.08 \%)$ and the Kyustendil area $(37.97 \%)$ give the greatest percentage of co-funding. The smallest percentage is in the Gabrovo area $(24.52 \%) .30 .24 \%$ is the average percentage of cofunding.

- During the second year of the program there is little to no change in the aforementioned percentages. Schools in the Kyustendil area (34.48\%) give the greatest percentage of cofunding. The smallest percentage is in the Silistra area (26.77\%). $29.45 \%$ is the average percentage of co-funding.

- The percentage of co-funding is greatest in the third year, with an average of $37.43 \%$. Schools in the Stara Zagora area contributed $49.24 \%$, a stark contrast with the Pernik area where schools contributed the least $-30.94 \%$.

\section{Conclusion}

The analysis of the National program "ICT in schools" $(2012-2015)$ shows that the program fails to achieve its goals - namely, renovating the ICT equipment, computerized workstations in particular, in all schools in the country for the entire duration of the analyzed period. More than $50 \%$ of the schools have not taken advantage of the program in the past three years. Despite the great interest in the program in the first year, applicants decreased in the second, perhaps because of the fixed prerequisite - "terminal workstations". This called for a change in the conditions - personal computers, laptops and tablets were included in the list of components to be financed. Hardware and software were also included even though they cost money but do not provide new computerized workstations.

Another thing that might have contributed to the failure of the program is the prerequisite for cofunding, because of which only schools with a great number of students and large budgets were able to benefit from the program. Schools with fewer students and thus smaller delegated budgets would have had considerable difficulties for co-funding. If all students cannot have access to modern technology and education, it can be seen as financial discrimination. In order to fix that, in the third year all protected schools who applied were approved, regardless of the percentage of co-funding, but they were only 47.

In the 3rd year of the National program, it remains to be proven that the schools funded have achieved the ratio of 1 computer to 12 students (per computerized workstation) which is a prerequisite of the program since there has been no information about the number of the already available computerized workstations, prior to the National program.

\section{References:}

(2013). National Program "Information and Communication technologies (ICT) in the schools" for the school year 20122013. Sofia: Ministry of Education and Science. Retrieved from http://www.mon.bg/?h=downloadFile\&fileId=4009

(2015). National Program "Information and Communication technologies (ICT) in the schools" for the school year 20142015. Sofia: Ministry of Education and Sciecne. Retrieved from http://www.mon.bg/?h=downloadFile \&fileId=5664

European Schoolnet, University of Liège. (2012). Survey of Schools: ICT in Education. Country Profile: Bulgaria. Brussels: European Commission. Retrieved from https://ec.europa.eu/digital-agenda/sites/digitalagenda/files/Bulgaria\%20country\%20profile.pdf

Petrova, S. (2013). Report: Assessment of competence to solve problems in the PISA 2012. Sofia: Center for Education Assessment. Retrieved from http://www.ckoko.bg/upload/docs/2014-04/PS_Chapter_BGR.pdf 